\title{
Efektivitas Program Usaha Peningkatan Pendapatan Keluarga Sejahtera (UPPKS) untuk Pemberdayaan Masyarakat Miskin
}

\author{
Muntaha Mardhatillah \\ Universitas Mohammad Natsir Bukittinggi, Bukitinggi \\ iilmuntaha@gmail.com
}

\begin{abstract}
$B K K B N$ as an organizer of family empowerment of the government to create a program Families Economic Empowerment by forming a group container (UPPKS), which is in its implementation in the city of Padang Panjang still encountered a number of problems. The purpose of this research is to determine the level of program effectiveness (UPPKS) in empowering the poor in Padang Panjang city, here are also seen what obstacles are encountered during program implementation and what efforts can be made to overcome these obstacles. The method used in this research is mixed methods were used to measure the effectiveness of the UPPKS program using the model of evaluation CIPO by Stufflebeam, then to get deeper conclusions regarding the results of the study used qualitative methods through observation and interviews. The research findings indicate that the effectiveness program (UPPKS) for empowerment of the poor in Padang Panjang been effective with $70.55 \%$ good category. Although the implementation of the program UPPKS in accordance with existing procedures but has not been fully able to improve the welfare of its members. This can be seen with still found some constraints in implementation, obstacles encountered can be categorized into two forms of internal constraints and external constraints. Internal constraints such as: weak supervision of the program, the lack of capital coming from the government, coaching is not evenly distributed. External constraints such as: the use of aid funds is not maximized, the lack of creativity and innovation groups in finding and utilizing financial resources, delays in repayment of the loan. Efforts are made to overcome these obstacles is to involve family welfare III acted as a foster father in group, guidance, and constraints derived from program participants made efforts such as mentoring, conducting proactive system for members jammed in payments.
\end{abstract}

Keywords: Effectiveness, Empowerment, Poverty, UPPKS Program

Submitted: July 27, 2020

Reviewed:February 23, 2021

Published: May 3, 2021

How to Cite: Muntaha Mardhatillah. 2021. Efektivitas Program Usaha Peningkatan Pendapatan Keluarga Sejahtera (UPPKS) untuk Pemberdayaan Masyarakat Miskin. Vol 5 (1): pp. 36-50. DOI: https://doi.org/10.24036/jess.v5i1

\section{Pendahuluan}

Kemiskinan adalah suatu keadaan di mana seseorang tidak sanggup memelihara dirinya sendiri sesuai dengan ukuran kehidupan kelompoknya, dan juga tidak mampu memanfaatkan tenaga mental maupun fisiknya dalam kelompok tersebut (Soekanto, 2010). Kemiskinan ini sangat berdampak pada kehidupan masyarakat, seperti tingginya angka pengangguran, keterbelakangan dan ketidakberdayaan di kalangan masyarakat. 
Sebagai salah satu kota terkecil dengan luas 2.300 Ha atau sekitar 0,05 persen dari luas Sumatera Barat, Kota Padang Panjang tidak luput dari masalah kemiskinan. Kota Padang Panjang menduduki peringkat ke 17 dari 19 Kab/Kota yang ada di Sumatera Barat dalam tingkat kemiskinan. Berdasarkan pengamatan penulis dari dua kecamatan yang ada di Kota Padang Panjang yaitu Padang Panjang Barat dan Padang Panjang Timur yang masing-masing memiliki delapan kelurahan tercatat beberapa masyarakat berada pada garis kemiskinan (Badan Pusat Statistik Kota Padang Panjang 2013).

Tabel 1 Rekapitulasi Kemiskinan Kota Padang Panjang tahun 2015

\begin{tabular}{llccc}
\hline \multirow{2}{*}{ No } & \multicolumn{1}{c}{ Kelurahan } & \multicolumn{3}{c}{ Kategori Kemiskinan } \\
\cline { 3 - 5 } & & $\begin{array}{c}\text { Sangat Miskin } \\
\text { (Pra Sejahtera) }\end{array}$ & Miskin & $\begin{array}{c}\text { Hampir } \\
\text { Miskin }\end{array}$ \\
\hline 1. & Silaing Bawah & 169 & 306 & 370 \\
2. & Silaing Atas & 2 & 156 & 269 \\
3. & Pasar Usang & 0 & 95 & 484 \\
4. & Pasar Baru & 52 & 257 & 98 \\
5. & Balai-Balai & 54 & 340 & 273 \\
6. & Tanah Hitam & 154 & 366 & 40 \\
7. & Kampung Manggis & 29 & 513 & 362 \\
8. & Bukit Surungan & 90 & 185 & 150 \\
9. & Ganting & 504 & 47 & 161 \\
10. & Sigando & 337 & 216 & 151 \\
11. & Ekor Lubuk & 178 & 230 & 293 \\
12. & Ngalau & 261 & 235 & 134 \\
13. & Tanah Pak Lambik & 0 & 236 & 0 \\
14. & Guguk Malintang & 0 & 581 & 0 \\
15. & Koto Panjang & 167 & 245 & 536 \\
16. & Koto Katik & 0 & 93 & 49 \\
\hline & Jumlah & 1997 & 4101 & 3370 \\
\hline
\end{tabular}

Sumber: Dinas Sosial Kota Padang Panjang 2015

Data yang didapat dari Kantor Pemberdayaan Perempuan dan Keluarga Berencana Kota Padang Panjang tahun 2015 mengenai tingkat kemiskinan yang ada di Kota Padang Panjang, memperlihatkan dari 47.619 jiwa penduduk masih terdapat penduduk miskin, hal ini sesuai dengan yang tergambar pada tabel di atas, yaitu sebanyak 1.997 jiwa tergolong kepada pra sejahtera, 4.101 jiwa tergolong miskin dan 3.370 jiwa tergolong hampir miskin.

Adapun upaya yang dilakukan pemerintah Kota Padang Panjang untuk memberantas kemiskinan adalah melalui pendekatan pemberdayaan keluarga. Pemberdayaan keluarga merupakan upaya untuk memandirikan keluarga lewat perwujudan kompetensi yang dimiliki keluarga yang mengacu pada UU No.10 Tahun 1992 tentang Perkembangan Kependudukan dan Pembangunan Keluarga Sejahtera yang pelaksanaannya diatur dalam Inpres Nomor 3 Tahun 1996 tentang Pembangunan Keluarga Sejahtera dalam Rangka Peningkatan Penanggulangan Kemiskinan. Kemudian diperbaharui melalui UU No.52 Tahun 2009, yang menekankan agar keluarga dibekali dengan berbagai kemampuan, sehingga dapat 
meningkatkan taraf perekonomian dan sosial menuju arah yang lebih baik. Salah satu lembaga yang mengatur kegiatan ini adalah Badan Kesejahteraan Keluarga Berencana Nasional (BKKBN). BKKBN menyusun sebuah program kegiatan pemberdayaan ekonomi keluarga dalam kelompok Usaha Peningkatan Pendapatan Keluarga Sejahtera (UPPKS) yang dijalankan oleh Kantor Pemberdayaan Perempuan Kota Padang Panjang.

UPPKS sebenarnya sudah berdiri dari tahun 1990 dengan nama Usaha Peningkatan Pendapatan Keluarga Akseptor (UPPKA). Dulu tujuannya hanya untuk mengembangkan potensi peserta KB. Namun dengan pergantian nama sekarang, maka tujuannya juga sudah dikembangkan lebih luas yaitu untuk meningkatkan kesejahteraan keluarga (BKKBN 2005). UPPKS dikembangkan melalui pendekatan kelompok dengan memberikan modal untuk setiap kegiatan yang akan dilaksanakan oleh kelompok. Kegiatan ini lebih diprioritaskan pada kelompok wanita untuk kelompok pra sejahtera, kemudian kelompok miskin dan kelompok hampir miskin. Biasanya setiap kelompok terdiri dari 10 sampai 20 orang per kegiatan. Setiap kelompok memiliki kepengurusan mulai dari ketua, sekretaris dan bendahara. Selanjutnya, setiap kelompok dibimbing oleh Keluarga Sejahtera III Plus (Bapak angkat) (BKKBN 2011).

Kelompok UPPKS di kota Padang Panjang sekarang ini sudah berjumlah 45 kelompok UPPKS yang tersebar di 16 kelurahan yang ada di kota Padang Panjang (Kantor Pemberdayaan Perempuan dan Keluarga Berencana Kota Padang Panjang 2012). Berdasarkan wawancara dan pengamatan penulis dalam program UPPKS ditemui sejumlah fenomena berikut: 1) masih kurangnya sosialisasi program UPPKS pada masyarakat Kota Padang Panjang dilihat dari belum sepenuhnya masyarakat miskin ikut berperan dalam program ini. 2) Terlalu banyaknya keragaman jenis usaha pada setiap kelompok. Seharusnya setiap kelompok hanya punya satu jenis usaha. Namun para anggota menggunakan untuk berbagai usaha. Hal ini tentu berdampak pada kinerja kelompok. Seperti yang terjadi pada kelompok UPPKS Flamboyan yang berada di Kelurahan Silaing Bawah Kecamatan Padang Panjang Barat, kelompok ini memiliki berbagai jenis usaha: bordiran, berjualan, warung sembako, petani bunga dan pembuat kue. Hal ini mengakibatkan anggota menjalankan usahanya sendiri-sendiri tanpa adanya kerja sama yang terjalin antar anggota kelompok.

Selain itu tentunya juga berdampak pada masalah modal yang tersedia. Tentunya modal tidak akan cukup untuk membiayai berbagai kegiatan dalam satu kelompok. 3) Dalam kasus kelompok UPPKS Flamboyan terlihat kurangnya perhatian dan bimbingan dari Keluarga Sejahtera III Plus (Bapak Angkat). Selain itu peserta juga sering menyalahgunakan modal yang telah diberikan. Untuk itu sangat penting untuk meningkatkan peran dari Keluarga Sejahtera III Plus (Bapak Angkat), sehingga kegiatan semua kelompok terpantau dengan baik, 4) Terbatasnya modal yang disediakan oleh pemerintah. Modal yang diberikan oleh pemerintah terakhir di tahun 2008 berjumlah Rp 100.000.000, dan tentu dibagi sebanyak kelompok. Sehingga bisa diperkirakan masing-masing kelompok mendapat sekitar Rp.2.500.00,00 - Rp.5.000.000,00. Dengan dana sebanyak ini tentu juga berdampak pada produksi yang kurang berkualitas baik dari segi isi atau kemasan. 
Berdasarkan uraian di atas, penulis tertarik untuk mengungkap efektivitas program UPPKS dalam sebuah penelitian yang berjudul: "Efektivitas Program Usaha Peningkatan Pendapatan Keluarga Sejahtera (UPPKS) untuk pemberdayaan Masyarakat Miskin di Kota Padang Panjang". Penelitian ini bertujuan untuk menganalisis efektivitas program usaha peningkatan pendapatan keluarga sejahtera dalam pemberdayaan masyarakat miskin di Kota Padang Panjang, kemudian menganalisis kendala dalam pelaksanaan program UPPKS, serta mengidentifikasi upaya apa saja yang dilakukan dalam mengatasi kendala tersebut.

\section{Tinjauan Kepustakaan}

\section{Efektivitas}

Efektivitas merupakan salah satu unsur pokok dalam mencapai tujuan atau sasaran yang telah ditentukan di dalam setiap organisasi, kegiatan atau program. Dikatakan efektif jika suatu tujuan ataupun sasaran yang sudah ditentukan tersebut dapat tercapai dengan baik. Efektivitas didefinisikan oleh banyak ahli, salah satunya definisi efektivitas menurut Sondang adalah pemanfaatan sumber daya, sarana dan prasarana dalam jumlah tertentu yang secara sadar ditetapkan sebelumnya untuk menghasilkan sejumlah barang atas jasa kegiatan yang dijalankannya (Sondang P. Siagian, 2001).

Lebih lanjut menurut (Agung, 2005) dalam bukunya Transformasi Pelayanan Publik mendefinisikan efektivitas "kemampuan melaksanakan tugas, fungsi (operasi kegiatan program atau misi) daripada suatu organisasi atau sejenisnya yang tidak adanya tekanan atau ketegangan diantara pelaksanaannya" Dari dua pendapat di atas dapat disimpulkan bahwa efektivitas adalah suatu ukuran yang menyatakan seberapa jauh target (kuantitas, kualitas dan waktu) yang telah dicapai oleh manajemen yang mana target tersebut sudah ditentukan terlebih dahulu.

Mengukur efektivitas organisasi bukanlah suatu hal yang sangat sederhana, karena efektivitas dapat dikaji dari berbagai sudut pandang dan tergantung pada siapa yang menilai serta menginterpretasikannya. Bila dipandang dari sudut produktivitas, maka seorang manajer produksi memberikan pemahaman bahwa efektivitas berarti kualitas dan kuantitas (output) barang dan jasa. Tingkat efektivitas juga dapat diukur dengan membandingkan antara rencana yang telah ditentukan dengan hasil nyata yang telah diwujudkan. Namun, jika usaha atau hasil pekerjaan dan tindakan yang dilakukan tidak tepat sehingga menyebabkan tujuan tidak tercapai atau sasaran yang diharapkan, maka hal itu dikatakan tidak efektif (Luas, Kimbal, dan Singkoh, 2017).

Adapun kriteria atau ukuran mengenai pencapaian tujuan efektif atau tidak, sebagaimana dikemukakan oleh (Sondang P. Siagian, 2001), yaitu:

a) Kejelasan tujuan yang hendak dicapai, hal ini dimaksudkan supaya karyawan dalam pelaksanaan tugas mencapai sasaran yang terarah dan tujuan organisasi dapat tercapai.

b) Kejelasan strategi pencapaian tujuan, telah diketahui bahwa strategi adalah "pada jalan" yang diikuti dalam melakukan berbagai upaya dalam mencapai sasaran-sasaran yang ditentukan agar para implementor tidak tersesat dalam pencapaian tujuan organisasi. 
c) Proses analisis dan perumusan kebijakan yang mantap, berkaitan dengan tujuan yang hendak dicapai dan strategi yang telah ditetapkan artinya kebijakan harus mampu menjembatani tujuan-tujuan dengan usaha-usaha pelaksanaan kegiatan operasional.

d) Perencanaan yang matang, pada hakikat nya berarti memutuskan sekarang apa yang dikerjakan oleh organisasi di masa depan.

e) Penyusunan program yang tepat suatu rencana yang baik masih perlu dijabarkan dalam program-program pelaksanaan yang tepat sebab apabila tidak, para pelaksana akan kurang memiliki pedoman bertindak dan bekerja.

f) Tersedianya sarana dan prasarana kerja, salah satu indikator efektivitas organisasi adalah kemampuan bekerja secara produktif. Dengan sarana dan prasarana yang tersedia dan mungkin disediakan oleh organisasi.

g) Pelaksanaan yang efektif dan efisien, bagaimanapun baiknya suatu program apabila tidak dilaksanakan secara efektif dan efisien maka organisasi tersebut tidak akan mencapai sasarannya, karena dengan pelaksanaan organisasi semakin didekatkan pada tujuannya.

h) Sistem pengawasan dan pengendalian yang bersifat mendidik mengingat sifat manusia yang tidak sempurna maka efektivitas organisasi menuntut terdapatnya sistem pengawasan dan pengendalian.

Dalam penelitian ini untuk mengukur efektivitas suatu organisasi ada tiga pendekatan yang dapat digunakan, seperti yang dikemukakan oleh (Lubis dan Huseini, 2007) yakni:

a) Pendekatan Sumber (resource approach) yakni mengukur efektivitas dari input. Pendekatan mengutamakan adanya keberhasilan organisasi untuk memperoleh sumber daya, baik fisik maupun non fisik yang sesuai dengan kebutuhan organisasi.

b) Pendekatan proses (process approach) adalah untuk melihat sejauh mana efektivitas pelaksanaan program dari semua kegiatan proses internal atau mekanisme organisasi.

c) Pendekatan sasaran (goals approach) dimana pusat perhatian pada output, mengukur keberhasilan organisasi untuk mencapai hasil (output) yang sesuai dengan rencana.

Dengan menggunakan teori ini diharapkan dapat mengukur tingkat efektivitas. Dalam hal ini adalah efektivitas program usaha peningkatan pendapatan keluarga sejahtera (UPPKS) di Kota Padang Panjang. Jadi yang menjadi indikator yang akan diteliti dalam penelitian ini adalah efektivitas dalam hal input, proses dan output. Untuk melihat keefektifan sebuah program tidak dapat dipisahkan dari konsep evaluasi program.

\section{Pemberdayaan Masyarakat}

\section{a. Pengertian Pemberdayaan Masyarakat}

Masyarakat miskin dan sangat miskin harus diberdayakan untuk dapat berpartisipasi lebih efektif dalam proyek dan program pembangunan yang dicanangkan oleh pemerintah. Menurut Soetomo pemberdayaan berisi kewenangan dan kemampuan. Keduanya tidak dapat dipisahkan, karena walaupun sudah 
memperoleh kewenangan, akan tetapi masyarakat belum atau tidak mempunyai kemampuan untuk menjalankan dan melaksanakan kewenangan tersebut, maka pemberdayaan belum terwujud (Soetomo, 2011). Pemberdayaan masyarakat seharusnya memberi mereka kesempatan untuk menunjukkan bahwa mereka dapat memberikan gagasan baik dan mempunyai keterampilan mewujudkan gagasannya menjadi realitas.

Pemberdayaan membantu menghilangkan kondisi yang menyebabkan ketidak berdayaan sambil meningkatkan perasaan self-efficacy pekerja. Selfefficacy adalah suatu perasan bahwa dirinya mampu menyelesaikan pekerjaan apa saja yang diberikan kepadanya. Namun self-efficacy perlu didukung dengan kemampuan actual (Wibowo, 2011). Pemberdayaan masyarakat dapat dilihat dari dua sisi keberadaannya yaitu sebagai program dan proses. Pemberdayaan sebagai suatu program, dimana pemberdayaan dilihat dari tahapan-tahapan kegiatan guna mencapai tujuan, yang biasanya sudah ditentukan jangka waktunya. Pemberdayaan masyarakat sebagai proses adalah kegiatan yang berkesinambungan (on-going) sepanjang komunitas itu masih ingin melakukan perubahan dan perbaikan, dan tidak hanya terpaku pada suatu program saja. (Isbandi, 2008).

Menurut (Suharto, 2005) "Pemberdayaan menunjuk kepada kemampuan orang, khususnya kelompok rentan dan lemah sehingga mereka memiliki kekuatan atau kemampuan dalam (a) memenuhi kebutuhan dasarnya sehingga mereka memiliki kebebasan (freedom), dalam arti bukan saja bebas mengemukakan pendapat, melainkan bebas dari kelaparan, bebas dari kebodohan, bebas dari kesakitan; (b) menjangkau sumber-sumber produktif yang memungkinkan mereka dapat meningkatkan pendapatannya dan memperoleh barang-barang dan jasa-jasa yang mereka perlukan; dan (c) berpartisipasi dalam proses pembangunan dan keputusan-keputusan yang mempengaruhi mereka".

Jadi dapat disimpulkan bahwa pemberdayaan merupakan suatu cara atau proses yang memberikan orang lain kemampuan dan pengetahuan untuk meningkatkan taraf hidup mereka agar lebih sejahtera. Pemberdayaan masyarakat adalah upaya untuk menciptakan atau meningkatkan kapasitas masyarakat, baik secara individu maupun berkelompok, dalam memecahkan berbagai persoalan terkait upaya peningkatan kualitas hidup, kemandirian dan kesejahteraannya. Diperlukan perhatian dan keterlibatan yang besar dari aparatur-aparatur pemerintahan serta berbagai pihak terkait agar dapat menjamin keberlanjutan berbagai hasil yang dicapai

\section{b. Pemberdayaan perempuan dalam peningkatan ekonomi keluarga}

Peranan perempuan dalam pembangunan adalah hak dan kewajiban yang dijalankan oleh perempuan pada status atau kedudukan tertentu dalam pembangunan, baik pembangunan di bidang politik, ekonomi, sosial budaya maupun pembangunan di bidang pertahanan keamanan, baik di dalam keluarga maupun di dalam masyarakat.

Pemberdayaan masyarakat sebagai suatu pemikiran yang tidak dapat dilepaskan dari paradigma pembangunan yang berpusat pada rakyat. Setiap upaya pemberdayaan harus diarahkan pada penciptaan suatu lingkungan yang memungkinkan masyarakat untuk menikmati kehidupan yang jauh lebih baik, 
terutama pada masyarakat yang mengikuti program Usaha Peningkatan Pendapatan Keluarga Sejahtera (UPPKS), program ini memberikan pelatihan dan pendanaan bagi ibu-ibu rumah tangga agar dapat membuka lapangan usaha dengan cara memanfaatkan Sumber Daya Alam yang tersedia di lingkungan. Pemberdayaan senantiasa mempunyai dua pengertian yang saling terkait yaitu masyarakat yang belum berkembang sebagai pihak yang harus diberdayakan, dan pihak yang menaruh keperdulian sebagai pihak yang memberdayakan (Ririn Kurniawati, Khomsun Nurhalim, 2017).

Peningkatan kesejahteraan keluarga dilakukan melalui perubahan perilaku peningkatan kesadaran kemampuan dan peran serta keluarga dalam memenuhi kebutuhan dasar seperti kebutuhan rohani, pangan, sandang, pendidikan dan kesehatan termasuk keluarga berencana. Sedangkan peningkatan kesejahteraan di bidang ekonomi bertujuan untuk menumbuhkan dan meningkatkan minat, semangat serta keterampilan ibu - ibu di bidang usaha ekonomi produktif.

Tujuan pemberdayaan masyarakat adalah meningkatkan pendapatan dan kesejahteraan keluarganya, baik dengan meningkatkan usaha yang ada maupun dengan menciptakan kesempatan kerja baru serta meningkatkan daya tawar mereka melalui pendampingan yang partisipatif dan berkelanjutan. Selain itu, pemberdayaan masyarakat bertujuan untuk meningkatkan potensi masyarakat agar mampu meningkatkan kualitas hidup yang lebih baik bagi seluruh warga masyarakat melalui kegiatankegiatan swadaya. Untuk mencapai tujuan ini, faktor peningkatan kualitas Sumber Daya Manusia melalui pendidikan formal dan nonformal perlu mandapat prioritas. (Ririn Kurniawati dan Khomsun Nurhalim, 2017).

Human Capital Theory, menekankan bahwa manusia merupakan sumber daya utama dalam upaya meningkatkan taraf hidup dirinya maupun dalam melestarikan dan memanfaatkan lingkungannya. Menurut (Roesmidi dan Riyanti, 2006) pemberdayaan perempuan seringkali digunakan dalam konteks kemampuan meningkatkan keadaan ekonomi (pemenuhan kebutuhan praktis) individu, yang merupakan prasyarat pemberdayaan. Definisi tersebut mencerminkan bahwa proses pemberdayaan perempuan merupakan tindakan usaha perbaikan atau peningkatan ekonomi, sosial budaya, politik dan psikologi baik secara individual maupun kolektif yang berbeda menurut kelompok etnik dan kelas sosial.

\section{Kemiskinan}

Masalah kemiskinan melibatkan seluruh aspek kehidupan manusia. Bagi mereka yang tergolong miskin, kemiskinan merupakan sesuatu yang nyata dalam kehidupannya sehari-hari. Mereka merasakan dan menjalani sendiri bagaimana hidup dalam kemiskinan. Walaupun demikian mereka belum tentu menyadari kemiskinan yang mereka alami. Kesadaran akan kemiskinan baru terasa pada waktu mereka membandingkan kehidupan yang mereka jalani dengan kehidupan orang lain yang mempunyai tingkat kehidupan sosial dan ekonomi yang lebih tinggi.

Kemiskinan dapat didefinisikan sebagai standar kehidupan yang rendah, yaitu adanya suatu tingkat kekurangan materi pada sejumlah orang dibandingkan dengan standar kehidupan umum yang berlaku dalam masyarakat yang bersangkutan. Kemiskinan seperti itu disebut kemiskinan relatif (Panjaitan, 2000). Kemiskinan, 
sebagaimana telah dijelaskan, sesungguhnya berakar dari inti masalah kemiskinan itu sendiri, yang oleh Robert (dalam Halim, 2005) disebut deprivation trap atau "perangkap kemiskinan". Secara rinci deprivation trap terdiri dari lima unsur, yaitu: kemiskinan itu sendiri, kelemahan fisik, keterasingan atau kadar isolasi, kerentanan, dan ketidak berdayaan. Kelima unsur ini sering kali berkait satu sama lain sehingga merupakan perangkap kemiskinan yang benar-benar berbahaya dan mematikan peluang hidup orang atau keluarga miskin.

Dalam pelaksanaan program UPPKS yang dimotori oleh Badan Kependudukan dan Keluarga Berencana Nasional (BKKBN), kriteria yang digunakan untuk menentukan keluarga yang akan memperoleh bantuan pada program ini adalah kriteria yang dikeluarkan oleh BKKBN. Kriteria BKKBN untuk mereka yang tergolong miskin adalah keluarga yang berada dalam kategori pra-KS dan KS I.

Adapun yang dimaksud dengan kategori pra-KS dan KS I adalah:

1. Tahapan Keluarga Pra Sejahtera (KPS), yaitu keluarga yang tidak memenuhi salah satu dari 6 (enam) indikator Keluarga Sejahtera I (KS I) atau indikator "kebutuhan dasar keluarga" (basic needs). Enam Indikator tahapan Keluarga Sejahtera I (KS I) atau indikator "kebutuhan dasar keluarga" (basic needs), yaitu: a) pada umumnya anggota keluarga makan dua kali sehari atau lebih, b) anggota keluarga memiliki pakaian yang berbeda untuk di rumah, bekerja/sekolah dan bepergian, c) rumah yang ditempati keluarga mempunyai atap, lantai dan dinding yang baik, d) bila ada anggota keluarga sakit dibawa ke sarana kesehatan, e) bila pasangan usia subur ingin ber-KB pergi ke sarana pelayanan kontrasepsi, f) Semua anak umur 7-15 tahun dalam keluarga bersekolah.

2. Tahapan Keluarga Sejahtera I (KSI), yaitu keluarga mampu memenuhi 6 (enam) indikator tahapan KS I, tetapi tidak memenuhi salah satu dari 8 (delapan) indikator Keluarga Sejahtera II atau indicator "kebutuhan psikologis" (psychological needs) keluarga. Delapan indikator Keluarga Sejahtera II (KS II) atau indikator "kebutuhan psikologis" (psychological needs) keluarga, yaitu: a) pada umumnya anggota keluarga melaksanakan ibadah sesuai dengan agama dan kepercayaan masing-masing, b) paling kurang sekali seminggu seluruh anggota keluarga makan daging/ikan/telur, c) seluruh anggota keluarga memperoleh paling kurang satu stel pakaian baru dalam setahun, d) luas lantai rumah paling kurang $8 \mathrm{~m} 2$ untuk setiap penghuni rumah, e) tiga bulan terakhir keluarga dalam keadaan sehat sehingga dapat melaksanakan tugas/fungsi masing-masing, f) ada seorang atau lebih anggota keluarga yang bekerja untuk memperoleh penghasilan, g) seluruh anggota keluarga umur 10-60 tahun bisa baca tulisan latin, h) pasangan usia subur dengan anak dua atau lebih menggunakan alat/obat kontrasepsi.

3. Tahapan Keluarga Sejahtera II, yaitu keluarga yang mampu memenuhi 6 (enam) indikator tahapan KS I dan 8 (delapan) indikator KS II, tetapi tidak memenuhi salah satu dari 5 (lima) indikator Keluarga Sejahtera III (KS III), atau indikator "kebutuhan pengembangan" (developmental needs) dari keluarga. Lima indikator Keluarga Sejahtera III (KS III) atau indikator "kebutuhan pengembangan" (developmental needs), yaitu: a) keluarga 
berupaya meningkatkan pengetahuan agama, b) sebagian penghasilan keluarga ditabung dalam bentuk uang atau barang, c) kebiasaan keluarga makan bersama paling kurang seminggu sekali dimanfaatkan untuk berkomunikasi, d) keluarga ikut dalam kegiatan masyarakat di lingkungan tempat tinggal, dan e) keluarga memperoleh informasi dari surat kabar/majalah/radio/tv/internet.

4. Tahapan Keluarga Sejahtera III, yaitu keluarga yang mampu memenuhi 6 (enam) indikator tahapan KS I, 8 (delapan) indikator KS II, dan 5 (lima) indikator KS III, tetapi tidak memenuhi salah satu dari 2 (dua) indikator Keluarga Sejahtera III Plus (KS III Plus) atau indikator "aktualisasi diri” (self esteem) keluarga. Dua indikator Keluarga Sejahtera III Plus (KS III Plus) atau indikator "aktualisasi diri" (self esteem), yaitu: a) keluarga secara teratur dengan suka rela memberikan sumbangan materi untuk kegiatan sosial dan b) ada anggota keluarga yang aktif sebagai pengurus perkumpulan sosial/yayasan/ institusi masyarakat.

5. Tahapan Keluarga Sejahtera III Plus, yaitu keluarga yang mampu memenuhi keseluruhan dari 6 (enam) indikator tahapan KS I, 8 (delapan) indikator KS II, 5 (lima) indikator KS III, serta 2 (dua) indikator tahapan KS III Plus.

\section{Kendala dalam Pelaksanaan Program}

Kendala yang ditemui dalam pelaksanaan pemberdayaan masyarakat miskin pada umumnya mengalami keterbatasan dalam kegiatan operasionalnya. Menurut D. R., M. E. \& Heitger (2012), jenis kendala berdasarkan asalnya adalah sebagai berikut.

1) Kendala internal, merupakan faktor -faktor yang membatasi suatu instansi yang berasal dari dalam berupa kendala sumber daya. Dalam penelitian ini kendala berupa kurang profesionalnya kinerja tim pelaksana kegiatan dalam melaksanakan tugasnya.

2) Kendala eksternal, merupakan faktor-faktor yang berasal dari luar instansi. Kendala dari luar dapat berupa pengaruh lingkungan tempat pelaksanaan pemberdayaan masyarakat miskin tersebut.

\section{Upaya Mengatasi Kendala Efektivitas}

Kartasasmita (1995) mengatakan bahwa upaya pemberdayaan masyarakat miskin dapat dilakukan melalui tiga tahap yaitu:

1) Menciptakan iklim yang memungkinkan potensi masyarakat berkembang. Titik tolaknya adalah pengenalan bahwa setiap manusia dan masyarakat memiliki potensi yang dapat dikembangkan. Pemberdayaan adalah upaya untuk mendorong, memberikan motivasi, dan membangkitkan kesadaran akan potensi yang dimilikinya serta berupaya untuk mengembangkan.

2) Memperkuat potensi atau daya yang memiliki masyarakat (empowering). Dalam rangka ini diperlukan langkah-langkah yang lebih positif dan nyata, penyediaan berbagai masukan, serta pembukaan akses ke berbagai peluang 
yang akan membuat masyarakat menjadi makin berdaya dalam memanfaatkan peluang.

3) Memberdayakan mengandung arti melindungi. Dalam proses pemberdayaan harus dicegah yang lemah menjadi semakin lemah, dan menciptakan kebersamaan serta kemitraan antara yang sudah maju dan yang belum maju/berkembang. Secara khusus perhatian harus diberikan dengan keberpihakan melalui pembangunan ekonomi rakyat, yaitu ekonomi usaha kecil, agar tidak tetinggal jauh, melainkan dapat memanfaatkan momentum globalisasi bagi perkembangannya.

Dari pendapat para ahli diatas dapat disimpulakan, bahwa pemberdayaan masyarakat miskin lebih menekankan kepada aspek kemandirian dengan memberikan bantuan dari pemerintah guna meningkatkan potensi yang dimiliki oleh masyarakat itu sendiri

\section{Metode Penelitian}

Penelitian ini menggunakan metode penelitian evaluatif dengan pendekatan kuantitatif deskriptif. Desain penelitian ini dipilih dengan pertimbangan untuk mengevaluasi pelaksanaan program usaha peningkatan pendapatan keluarga sejahtera (UPPKS) di Kota Padang Panjang, model evaluasi yang digunakan adalah model evaluasi CIPP (Context, Input, Process, dan Product). Model evaluasi CIPP dipilih karena aspek yang ditinjau dalam model penelitian ini dianggap lebih komprehensif dibandingkan dengan model evaluasi lainnya. Penelitian menggunakan metode gabungan yang dilakukan secara bersamaan dengan tujuan untuk saling melengkapi gambaran hasil studi mengenai fenomena yang diteliti dan memperkuat hasil analisis penelitian.

Penelitian ini berisi deskripsi dan analisis tentang Efektivitas Program Usaha Peningkatan Pendapatan Keluarga Sejahtera (UPPKS) dalam Pemberdayaan Masyarakat Miskin di Kota Padang Panjang. Dalam penelitian ini yang menjadi Subjek adalah seluruh anggota kelompok UPPKS di Kota Padang Panjang pada tahun 2015 yaitu sebanyak 667 anggota yang tersebar pada 45 kelompok UPPKS dan dengan menggunakan rumus slovin diambil sebanyak 87 responden. Dari responden yang ada digunakan teknik cluster sampling.

Teknik pengumpulan data menggunakan angket, observasi dan wawancara serta studi dokumentasi. Alat pengumpulan data utama yang digunakan dalam penelitian adalah pedoman wawancara dan panduan observasi yang telah disiapkan sebelumnya dan dibantu dengan alat pengumpulan data lainnya berupa handphone yang digunakan untuk merekam proses wawancara dengan informan penelitian, dan catatan lapangan yang berisi data-data peneliti selama proses observasi. Sementara itu dalam langkah kuantitatif dilakukan dengan pembuatan angket dengan menggunakan skala likert untuk memberikan skor kepada setiap jawaban responden. Data yang diperoleh dari penelitian ini dianalisis dengan menggunakan teknik analisa data deskriptif kualitatif dan kuantitatif. Pada tahapan kuantitatif dilakukan dengan langkah verifikasi data angket dan tabulasi dengan cara menghitung frekuensi dari masing-masing jawaban responden. 


\section{Hasil dan Pembahasan}

\section{Efektivitas Pogram Usaha Peningkatan Pendapatan Keluarga Sejahtera (UPPKS)}

Program UPPKS yang dimotori oleh Badan Kependudukan dan Keluarga Berencana Nasional menetapkan sasaran dari program UPPKS ini, Adapun masyarakat yang berhak ikut serta ke dalam keanggotaan UPPKS ini yaitu kaum wanita yang termasuk kategori pra Keluarga Sejahtera (pra-KS), Sejahtera I, dan keluarga lain yang tingkat kesejahteraannya sudah lebih tinggi, yang akan dan sedang melakukan kegiatan usaha ekonomi produktif. Sasaran tidak langsung dari kegiatan ini antara lain adalah kader pembangunan di tingkat desa, tokoh masyarakat, penyuluh keluarga berencana (PLKB), dan pemberi pinjaman modal.

Program UPPKS dirasa sudah tepat sasaran, namun kontribusinya tergantung pada kelompok penerima bantuan tersebut untuk bisa mengelola dana yang telah dipinjamkan dengan baik, meskipun kontribusi program UPPKS belum memberikan dampak yang nyata bagi masyarakat, namun dengan bantuan modal usaha tersebut setidaknya sudah dapat memperbaiki kehidupannya untuk dapat lebih baik dalam mengurus rumah tangganya.

Bagi sebagian kelompok, besarnya bantuan awal yang diberikan dirasa tidak mencukupi kebutuhan akan modal kelompok UPPKS, dimana pinjaman modal awal yang didapat berkisar antara Rp. 2.500.000,- sampai Rp. 5.000.000,- harus dibagikan ke 10-20 orang anggota, sehingga kurang mampu mengembangkan usaha yang dilakukan oleh kelompok UPPKS. Namun tidak setiap kelompok berpendapat demikian, besar kecilnya bantuan tidak menghambat perkembangan usaha yang dilakukan kelompok, itu semua tergantung pada kreatifitas dan inovasi kelompok dalam memanfaatkan dana yang ada.

Tabel 3 Efektivitas Program Usaha Peningkatan Pendapatan Keluarga Sejahtera (UPPKS) Untuk Pemberdayaan Masyarakat Miskin di Kota Padang Panjang

\begin{tabular}{|c|c|c|c|c|}
\hline No & Kegiatan & Rerata & $\begin{array}{l}\text { TCR } \\
(\%)\end{array}$ & Kategori \\
\hline \multicolumn{5}{|c|}{ Input } \\
\hline 1. & Diberikan sosialisasi & 3.057 & 76.44 & $\begin{array}{l}\text { Sangat } \\
\text { Efektif }\end{array}$ \\
\hline 2 & \multirow[t]{2}{*}{ Sosialisasi menambah informasi } & & & Sangat \\
\hline 2. & & 3.149 & 78.74 & Efektif \\
\hline 3. & Bantuan modal sesuai dengan standar biaya & 2.632 & 65.80 & Efektif \\
\hline 4. & Bantuan modal sesuai dengan sasaran & 2.920 & 72.99 & Efektif \\
\hline \multicolumn{5}{|c|}{ Proses } \\
\hline 1. & Diberikan pembinaan secara berkala & 2.563 & 64.08 & Efektif \\
\hline 2. & $\begin{array}{l}\text { Pembinaan oleh nara sumber yang } \\
\text { berpengalaman }\end{array}$ & 2.425 & 60.63 & Efektif \\
\hline 3. & Kegiatan UPPKS dievaluasi secara berkala & 2.690 & 67.24 & Efektif \\
\hline 4. & Setelah evaluasi diberikan pembinaan & 2.517 & 62.93 & Efektif \\
\hline
\end{tabular}




\begin{tabular}{lllll} 
& Out Put & & & \\
1. & UPPKS meningkatkan kesejahteraan & & & Sangat \\
2. & UPPKS menghasilkan pendapatan baru & 2.126 & 78.16 & Efektif \\
3. $\quad$ UPPKS membantu untuk mendapatkan & & 74.14 & Efektif \\
barang dan jasa & 2.943 & 73.56 & Efektif \\
\hline & UPPKS mampu mengurangi pengangguran & 2.874 & 71.84 & Efektif \\
\hline \multicolumn{2}{l}{ Jumlah In Put + Proses + Out Put } & & $\mathbf{7 0 , 5 5}$ & Efektif \\
\hline
\end{tabular}

Bila dilihat dari data kuantitatif kegiatan UPPKS ini masih perlu ditingkatkan. Apalagi bila dilihat dari tingkat capaian masih berada pada kategori efektif yaitu 70,55\%. Tentunya masih perlu ditingkatkan lagi agar kegiatan ini dapat lebih efektif lagi kedepannya. Bila dilihat dari segi indikator input, kegiatan efektivitas program UPPKS ini juga sudah dilaksanakan dengan sebaik mungkin. Seperti dalam hal memberikan sosialisasi dengan tingkat capaian skor $76,44 \%$ pada kategori sangat efektif. Selain itu agar indikator input lebih baik juga, maka sosialisasi yang sudah ada sangat memberikan kontribusi untuk memberikan informasi bagi pengetahuan mereka dengan tingkat capaian skor $78,74 \%$ dengan kategori sangat efektif. Namun pada indikator bantuan modal yang diberikan dirasa kurang mencukupi bagi sebagian anggota kelompok hal ini terlihat dengan tingkat capaian yang rendah dibanding indikator input yang lain dengan skor $65.80 \%$.

Untuk melihat indikator proses dalam efektivitas ini juga telah efektif, pembinaan yang diberikan kepada anggota dirasa belum sepenuhnya diberikan kepada anggota kelompok UPPKS, indikator yang paling rendah yaitu pembinaan yang diberikan oleh narasumber yang sangat berpengalaman dengan skor $60.63 \%$. Pembinaan merupakan proses pemberdayaan yang bertujuan untuk meningkatkan kemampuan kelompok UPPKS sejalan dengan temuan Hasibuan (2015) menyatakan dalam membuat catatan keuangan yang baik mampu meningkatkan kemampuan UPPKS dalam memanajemen usahanya. Mampunya sebuah UPPKS melaksanakan pencatatan keuangan yang baik akan memberi nilai tambah dalam persaingan pasar.

Program UPPKS ini juga sudah menghasilkan produk dan jasa yang berkualitas. Hal ini dibuktikan dengan indikator output bahwa program UPPKS ini mampu meningkatkan kesejahteraan, pendapatan baru dan juga mendapatkan barang dan jasa. Selain itu indikator output-nya mampu mengurangi angka pengangguran dengan tingkat capaian skor $71,84 \%$ pada kategori efektif. Agar kegiatan UPPKS ini dapat efektif dilaksanakan maka harus banyak yang perlu ditingkatkan. Adapun yang perlu ditingkatkan adalah masalah pembinaan yang diberikan kepada kelompok UPPKS karena butir ini sangat rendah tingkat capaiannya yaitu $60.63 \%$. Senada dengan temuan penelitian oleh Sudarmaini dan Waini Astuti yang menyebutkan adanya anggota yang kurang aktif dalam kegiatan kelompok UPPKS, kader yang kurang cekatan dalam menangani masalah yang ada pada anggotanya menjadi hambatan dalam pelaksanaan program UPPKS sehingga pelatihan dan sosialisasi yang kurang maksimal dalam kelompok UPPKS (Waini Astuti, 2019).

Pembinaan ini juga sangat berguna agar masyarakat yang mengikuti kegiatan UPPKS ini semakin termotivasi, semakin kreatif dalam berbagai hal. Baik itu dalam 
hal pengemasan, pembuatan maupun dalam sistem pekerjaan. Kegiatan UPPKS ini perlu mendapat evaluasi yang dilakukan secara berkala. Setelah kegiatan evaluasi dilakukan maka sangat diperlukan juga pembinaan kepada peserta UPPKS. Hal ini dilakukan agar mereka dapat terbimbing dalam melaksanakan usaha mereka. Hal lain yang perlu ditingkatkan adalah masalah modal. Pemberdayaan ini diharapkan dapat menciptakan komunitas masyarakat yang hidup mandiri. Masyarakat yang mampu mengendalikan kehidupan mereka, keberhasilan sebuah program pemberdayaan tidak hanya ditentukan jumlah modal yang diberikan, akan tetapi oleh spirit dan komitmen subyek pemberdayaan. Selain itu, faktor lain yang mempengaruhi keberhasilan pemberdayaan ini adalah manajemen pengelolaan modal dan aset pemberdayaan (Mustofa dan Irwansyah, 2017).

Untuk memilih kegiatan tersebut maka diperlukan pembinaan tadi. Sehingga para peserta UPPKS dapat bertahan dengan usaha mereka. Selain itu, mereka harus bisa disiplin dalam penggunaan dana. Karena bila kegiatan UPPKS ini berhasil tentu akan mampu meningkatkan taraf kesejahteraan mereka, dan juga dapat mengurangi pengangguran. Bila dilihat secara umum kendala yang ditemui di lapangan juga sangat banyak data, walaupun tingkat capaiannya hanya $62,16 \%$ tapi masih perlu untuk mendapatkan perhatian agar kendala-kendala ini semakin menurun di lapangan. Kendala yang cukup banyak ditemui adalah indikator kendala internal (D. R., M. E. dan Heitger, 2012) yaitu kurang mampunya para peserta dalam membagi waktu dengan keluarga pada tingkat capaian $75 \%$. Sedangkan yang cukup teratasi adalah dalam indikator kendala eksternal dan sebagian kendala internal seperti termotivasi untuk ikut UPPKS agar wawasan bertambah. Selain itu sulitnya masalah transportasi dalam kegiatan UPPKS ini dengan tingkat capaian $58,62 \%$ pada kategori setuju.

Dengan meningkatkan hal-hal di atas maka sangat diharapkan program ini dapat efektif dan mampu mempertahankan usaha dalam jangka waktu yang lama dengan sasaran-sasaran yang telah ditetapkan. Sebagaimana yang dikemukakan oleh Annas dalam Irman menjelaskan bahwa: Efektivitas adalah tingkat pencapaian tujuan atau sasaran organisasional sesuai yang telah ditetapkan. Efektivitas merupakan seberapa baik pekerjaan dilakukan, sejauh mana seseorang menghasilkan keluaran sesuai yang diharapkan. Ini dapat diartikan bahwa apabila suatu pekerjaan dapat dilakukan dengan baik sesuai yang direncanakan, maka dapat dikatakan efektif (Irman Nurrachman Saputra, 2018).

Berdasarkan hasil temuan penelitian sudah ada beberapa upaya dari pemerintah. Pertama kali yang sudah dilakukan adalah sosialisasi UPPKS ini pada keluarga sejahtera III selaku bapak angkat. Bapak angkat membantu dalam hal permodalah, jaringan usaha, mapun keterampilan lain. Bapak angkat ini juga bertindak sebagai pembina terhadap kelompoknya baik sebagai investasi bagi keluarga sejahtera III plus itu sendiri. Hal ini juga terbukti dari hasil pengolahan data yang menunjukkan tingkat capaian yang diperoleh dari upaya yang dilakukan agar program UPPKS ini lebih efektif yaitu dengan skor 79,54\%, dengan kategori sangat setuju. Upaya yang dilakukan bisa dilihat dari indikator individu dan indiktor secara kolektif. Secara indikator individu seperti melakukan perencanaan yang matang dengan tingkat capaian sampai 79,60\% pada kategori setuju. Selanjutnya, upaya pada indikator kolektif itu berupa termotivasi dalam menanggulangi 
pengangguran. Ini sudah dilakukan upaya dengan tingkat capaian $80,75 \%$ pada kategori sangat setuju, hal ini senada dengan Umanollah (2018) yang berpendapat dalam menjalankan program pemberdayaan perlu diintegrasikan pada tingkatan struktur dan operasional yang dilakukan secara button up dan top down agar tidak terjadi penumpukan program.

Selain itu upaya dalam program UPPKS ini harus selalu ditingkatkan, karena mungkin tidak selamanya Bapak Angkat mampu memberikan pembinaan dalam program UPPKS ini. Menurut hemat peneliti, perlu dibentuk pengelola yang khusus untuk mensurvey ke lapangan agar kegiatan ini dapat berjalan sebagaimana mestinya. Bila perlu tim monevnya ditunjuk dari perguruan tinggi yang fakultasnya disesuaikan dengan bentuk jenis usaha yang diberikan

\section{Penutup}

Efektivitas program usaha peningkatan pendapatan keluarga sejahtera (UPPKS) dalam pemberdayaan masyarakat miskin di kota Padang Panjang sudah tergolong efektif, dengan ketercapaian $70,55 \%$, pengukuruan tingkat efektivitas program dilakukan dengan menggunakan model evaluasi CIPO dilihat dari segi input, proses dan output. Namun begitu masih ditemui beberapa permasalahan yang menghambat ketercapaian program dalam membantu meningkatkan kesejahteraan masyarakat miskin di Kota Padang Panjang, berbabagai upayapun telah dilakukan dalam peningkatan efektivitas program tersebut. Pembinaan sangat berguna agar masyarakat yang mengikuti kegiatan UPPKS ini semakin termotivasi, semakin kreatif dalam berbagai hal. Baik itu dalam hal pengemasan, pembuatan maupun dalam sistem pekerjaan. Kegiatan UPPKS ini perlu mendapat evaluasi yang dilakukan secara berkala. Setelah kegiatan evaluasi dilakukan maka sangat diperlukan juga pembinaan kepada peserta UPPKS. Hal ini dilakukan agar mereka dapat terbimbing dalam melaksanakan usaha mereka. Hal lain yang perlu ditingkatkan adalah masalah modal. Pemberdayaan ini diharapkan dapat menciptakan komunitas masyarakat yang hidup mandiri.

\section{DAFTAR KEPUSTAKAAN}

Agung, Kurniawan. 2005. Transformasi Pelayanan Publik. Yogyakarta: Pembaharuan.

Badan Pusat Statistik Kota Padang Panjang. 2013. Padang Panjang Dalam Angka 2012/2013. Padang Panjang: BPS Kota Padang Panjang.

BKKBN. 2005. Kelompok UPPKS Sebagai Model Pemberdayaan Ekonomi Keluarga. Jakarta: BKKBN.

BKKBN. 2011. Pedoman Pengelolaan Dan Pengembangan Kelompok UPPKS. Padang: BKKBN.

D. R., M. E., Hansen Mowen, and D. L. Heitger. 2012. Cornerstones of Managerial Accounting (4 Ed.). USA: South-Western: Cengage Learning.

Halim, Rr. Surhatini. 2005. Manajemen Pesantren. Yogyakarta: LKIS Pelangi Aksara.

Hasibuan, Ali Fikri. 2015. "Pemberdayaan UPPKS Cendrawasih Berbasis 
Pencatatan Keuangan Di Kota Tanjung Balai." Pengabdian Kepada Masyarakat 21(September):1-4.

Irman Nurrachman Saputra. 2018. "Efektivitas Pelaksanaan Program

Pemberdayaan Usaha Mikro Kecil Dan Menengah Di Kabupaten Ciamis." Jurnal Moderat 4(3):136-45.

Isbandi, Adi Rukminto. 2008. Intervensi Komunitas Pengembangan Masyarakat. Jakarta: PT Raja Grafindo Persada.

Kantor Pemberdayaan Perempuan dan Keluarga Berencana Kota Padang Panjang. 2012. Profil UPPKS Kota Padang Panjang. Padang Panjang: Kantor Pemberdayaan Perempuan dan Keluarga Berencana Kota Padang Panjang.

Kartasasmita, Ginanjar. 1995. Pemberdayaan Masyarakat: Sebuah Tinjauan Administrasi. Malang: Unibraw Press.

Luas, Jessica, Marthen Kimbal, and Frans Singkoh. 2017. "Efektivitas Pelayanan Publik Di Kelurahan Kakaskasen Dua Kecamatan Tomohon Utara Kota Tomohon." Jurnal Eksekutif 2(2).

Lubis, Hari, and Martani Huseini. 2007. Efektivitas Pelayanan Publik. Jakarta: Pustaka Binaman Presindo.

Mustofa, Imam, and Dedi Irwansyah. 2017. "Pemberdayaan Ekonomi Masyarakat Miskin-Kota Melalui Pengembangbiakkan Kambing." Akademika: Jurnal Pemikiran Islam 22(2):267-96.

Panjaitan, Merphin. 2000. Memberdayakan Kaum Miskin. Jakarta: Gramedia.

Ririn Kurniawati, Dr. Khomsun Nurhalim, M. P. 2017. "Pemberdayaan Usaha Peningkatan Pendapatan Keluarga Sejahtera dalam Pengelolaan Limbah Plastik." Journal of Chemical Information and Modeling 110(9):1689-99.

Roesmidi, and Riyanti. 2006. Pemberdayaan Masyarakat. Sumedang: Alqaprint Jatinangor.

Soekanto. 2010. Sosiologi Suatu Pengatar. Jakarta: PT Raja Grafindo Persada.

Soetomo. 2011. Pemberdayaan Masyarakat Mungkinkah Muncul Antitesisnya? Yogyakarta: Pustaka Pelajar.

Sondang P. Siagian. 2001. Manajemen Sumber Daya Manusia. Jakarta: Bumi Aksara.

Suharto, Eddi. 2005. Membangun Masyarakat Memberdayakan Masyarakat. Bandung: PT Refika Aditama.

Umanollah, Chairul. 2018. "Proceeding of Community Development " Memperkuat Produktivitas Untuk Ketahanan Ekonomi Nasional " Integration of Community Empowerment Models [ Pengintegrasian Model Pemberdayaan Masy ... Integration of Community Empowerment Models [ Pengintegrasian Model." Proceeding of Community Development 2(January 2018).

Waini Astuti, Sudarmiani,. 2019. "Pemberdayaan Ekonomi Keluarga Melalui Usaha Peningkatan Pendapatan Keluarga Sejahtera (UPPKS) (Studi Kasus Di Desa Sukorejo Kecamatan Saradan Kabupaten Madiun)." EQUILIBRIUM : Jurnal Ilmiah Ekonomi Dan Pembelajarannya 7(2):116. doi: 10.25273/equilibrium.v7i2.4777.

Wibowo. 2011. Manajemen Kinerja. Jakarta: PT Raja Grafindo Persada. 